\title{
Soil microbial biomass in cropland and forest ecosystem in eastern Nepal
}

\author{
T.N. Mandal \\ Department of Botany, Post Graduate Campus, Tribhuvan University \\ Biratnagar, Nepal \\ Email:tnmandal@gmail.com
}

\begin{abstract}
Soil microbial biomass carbon (MB-C) and nitrogen (MB-N) were estimated in some man-made cropland ecosystems and Sal forest natural ecosystem in eastern Nepal. In these cropping systems MB-C ranged between $244 \mu \mathrm{g} \mathrm{g}^{-1}$ and $425 \mu \mathrm{g} \mathrm{g}^{-1}$ soil, minimum in tea cultivation and maximum in uncultivated paddy field. MB $-\mathrm{N}$ ranged from $24.7 \mu \mathrm{g} \mathrm{g}^{-1}$ to $43.2 \mu \mathrm{g} \mathrm{g}^{-1}$ soil, which was minimum in paddy field at mature crop stage and maximum in uncultivated paddy field. Towards natural ecosystem five landslide damaged sites selected in Sal forest ecosystem were $1 \mathrm{yr}$., 4yr., 15yr., 40yr., and 58-

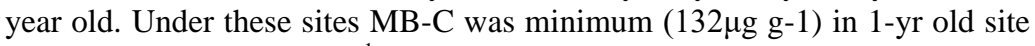
and maximum $\left(638 \mu \mathrm{g} \mathrm{g}^{-1}\right)$ in 58- yr old site. Similarly, MB-N was also minimum $\left(14 \mu \mathrm{g} \mathrm{g}^{-1}\right)$ in 1 -yr and maximum $(55 \mu \mathrm{g} \mathrm{g}-1)$ in $58-\mathrm{yr}$ old site. In comparison to undisturbed mature Sal forest 58 year old site showed $82 \%$ recovery in soil microbial biomass which indicates the re-establishment of soil nutrients and restitution of nutrients cycling.
\end{abstract}

Key words: Cropping system, tropical moist forest, landslide, restoration.

\section{Introduction}

Soil microbial biomass is a small, active, living and labile fraction of soil organic matter. Though, it represents a small fraction of total soil organic matter, but it is an active fraction due to its rapid turnover rate and fast release of available nutrients to the plants and thus contributing to nutrient cycling process far greater than its size (Schnurer et al., 1985). Century model divides the soil organic matter into three fractions with different turnover time: (a) active fraction with most rapid turnover time $(0.14 \mathrm{yr})$ (b) slow fraction having an intermediate turnover time $(5 \mathrm{yr})$ and (c) passive fraction with longest turnover time (150 yr) (Parton et al., 1989). The active fraction represents the live soil microbial biomass.

Soil microorganisms play a key role in the decomposition of complex organic matter of plant residues and the cycling of plant nutrients by acting both as a sink (immobilization) and as a source (mineralization) of plant nutrients (Fosu et al., 2007). The size of soil microbial biomass can be taken as functional index of soil fertility and indicator of soil quality. Soil microbial biomass carbon (MB-C) comprises 1-5\% of total organic carbon (Nsabimana et al., 2004). MB$\mathrm{C}$ could respond more rapidly to changes of soil environment than soil organic matter due to its high turnover rate (Powlson et al., 1987). Microbial biomass serves both as the transformation agent and source-sink of nitrogen (Bonde et al., 1998). Thus, microbial biomass nitrogen (MB$\mathrm{N}$ ) may have significant impacts on nitrogen availability and overall soil nitrogen cycling. 
Contribution of soil microbial biomass towards nutrients flow and organic matter turnover has led to use it as a tool for soil management and perturbation studies (Smith \& Paperdick, 1993). Informations on measurement and dynamics soil microbial biomass are available from dry tropical forest soil, mine spoils, grassland soil and agricultural soil (Srivastava \& Singh, 1991; Kujur \& Patel, 2012). However, the information on microbial biomass in different cropping systems is lacking. In the present investigation an attempt has been made to assess the level of soil microbial biomass in cropland (artificial ecosystem) and forest (natural ecosystem). Further, recovery pattern in soil microbial biomass has also been documented within a chronosequence of 1 to 58 yr old landslide damaged sites.

\section{Materials and Methods}

\section{Study Sites}

In the cropping ecosystem, study sites were selected in different croplands as: Paddy field- at beginning of cultivation, Paddy field with mature crop stage, Paddy field- uncultivated, Banana cultivation, Sugarcane cultivation and Tea cultivation in eastern Nepal. In the forest ecosystem, landslide damaged sites of $1 \mathrm{yr}, 4 \mathrm{yr}, 15 \mathrm{yr}, 40 \mathrm{yr}$ and $58 \mathrm{yr}$-old were selected in the tropical moist forest region in Eastern Siwaliks of Nepal. Comparisons were made with an undisturbed mature Sal forest located in the same region.

\section{Determination of microbial biomass $C$ and $N$}

Soils were collected from 3 random locations at each site. At each location, soil was collected from 3 pits, composited and pooled as one replicate. After carefully removing the organic materials and fine roots, composited field moist soil samples were sieved through a $2 \mathrm{~mm}$ mesh screen and were preconditioned for 7 days at room temperature. Soil microbial biomass C and N were estimated according to Brooks et al. (1985) and Vance et al. (1987).

\section{Results}

Soil microbial biomass in cropland system

Microbial biomass carbon (MB-C) ranged between $244 \mu \mathrm{g} \mathrm{g}^{-1}$ and $425 \mu \mathrm{g} \mathrm{g}^{-1}$ minimum in tea cultivation and maximum in uncultivated paddy field. Microbial biomass nitrogen (MB-N) ranged between $24.7 \mu \mathrm{g} \mathrm{g}^{-1}$ and $43.2 \mu \mathrm{g} \mathrm{g}^{-1}$, minimum in paddy field at mature crop stage and maximum in uncultivated paddy field (Table 1).

\begin{tabular}{lccc}
\hline $\begin{array}{l}\text { Table 1. Soil microbial biomass }\left(\mu \mathrm{g} \mathrm{g}^{1}\right) \text { in some cropping ecosystems } \\
\text { in eastern Nepal. }\end{array}$ & MB-C & MB-N & MB-C:NMB \\
\hline Study Sites & $352 \pm 34$ & $32.8 \pm 1.2$ & 10.7 \\
Paddy field-beginning cultivation & $280 \pm 15$ & $24.7 \pm 1.7$ & 11.3 \\
Paddy field-mature crop stage & $425 \pm 21$ & $43.2 \pm 1.7$ & 9.8 \\
Paddy field-uncultivated & $368 \pm 86$ & $32.5 \pm 1.5$ & 11.3 \\
Banana cultivation & $297 \pm 50$ & $27.0 \pm 1.5$ & 11.0 \\
Sugarcane cultivation & $244 \pm 45$ & $26.2 \pm 1.2$ & 9.3 \\
Tea cultivation & & & \\
\hline
\end{tabular}

MB-C:MB-N ratio was narrow in tea cultivation and wide in banana cultivation and paddy field at mature crop stage. Soil microbial biomass carbon and nitrogen as percentage of soil organic carbon and total nitrogen in cropland ecosystem are presented in table 2 . Percentage of microbial 
biomass carbon was higher $(5.2 \%)$ in banana cultivation and minimum $(2.2 \%)$ in tea cultivation. Similarly, percentage of microbial biomass nitrogen was also maximum $(6.5 \%)$ in banana cultivation and minimum $(2.9 \%)$ in tea and uncultivated paddy field.

Table 2. Soil microbial biomass $\mathrm{C}$ and $\mathrm{N}$ as $\%$ of soil organic $\mathrm{C}$ and total $\mathrm{N}$ in some cropping ecosystems in eastern Nepal.

\begin{tabular}{lcc}
\hline \multirow{2}{*}{ Study Sites } & \multicolumn{2}{c}{ Microbial Biomass \% of } \\
\cline { 2 - 3 } & Organic C & Total N \\
\hline Paddy field-beginning cultivation & 4.3 & 5.5 \\
Paddy field-mature crop stage & 3.8 & 3.5 \\
Paddy field- uncultivated & 3.4 & 2.9 \\
Banana cultivation & 5.2 & 6.5 \\
Sugarcane cultivation & 4.4 & 5.4 \\
Tea cultivation & 2.2 & 2.9 \\
\hline
\end{tabular}

Soil microbial biomass in Sal forest ecosystem

In the natural ecosystem the level of soil microbial biomass carbon and nitrogen were higher than cultivated ecosystem. The soil of mature Sal forest stand contained $778 \mu \mathrm{g} \mathrm{g}^{-1} \mathrm{MB}-\mathrm{C}$ and 65 $\mu \mathrm{g} \mathrm{g}^{-1} \mathrm{MB}-\mathrm{N}$ (Table 3). In the Sal forest region landslide damaged site of different age showed minimum MB-C $\left(132 \mu \mathrm{g} \mathrm{g}^{-1}\right)$ and MB-N $\left(14 \mu \mathrm{g} \mathrm{g}^{-1}\right)$ in $1 \mathrm{yr}-$ old site and maximum MB-C (638 $\left.\mu \mathrm{g} \mathrm{g}^{-1}\right)$ and MB-N $\left(55 \mu \mathrm{g} \mathrm{g}^{-1}\right)$ in $58 \mathrm{yr}$ - old landslide site. MB-C: MB-N ratio was narrow (9.4) at $1 \mathrm{yr}$ - old site and wide (12.0) is undisturbed mature Sal forest stand. Soil microbial biomass carbon and nitrogen as percentage of soil organic carbon and total nitrogen was lower in natural forest ecosystem than in cultivated cropland system (Table 4).

Table 3. Soil microbial biomass $\left(\mu \mathrm{g} \mathrm{g}^{-1}\right)$ in landslide sites and mature Sal forest in eastern Nepal.

\begin{tabular}{lccc}
\hline Study site & MB-C & MB-N & MB-C:MB-N \\
\hline $\begin{array}{l}\text { Landslides sites } \\
\text { (Age-year) }\end{array}$ & & & \\
\hline 1 year & $132 \pm 13$ & $14 \pm 1.7$ & 9.4 \\
4 year & $215 \pm 18$ & $21 \pm 2.3$ & 10.2 \\
15 year & $408 \pm 30$ & $38 \pm 3.3$ & 10.7 \\
40 year & $568 \pm 43$ & $50 \pm 4.6$ & 11.4 \\
58 year & $638 \pm 43$ & $55 \pm 3.9$ & 11.6 \\
\hline Mature Sal forest & $778 \pm 51$ & $65 \pm 5.4$ & 12.0 \\
\hline
\end{tabular}

Table 4. Soil microbial biomass $\mathrm{C}$ and $\mathrm{N}$ as percentage of organic $\mathrm{C}$ and total $\mathrm{N}$, respectively in landslide sites and mature Sal forest in eastern Nepal.

\begin{tabular}{lcc}
\hline Landslide sites & \multicolumn{2}{c}{ Microbial Biomass as \% of } \\
\cline { 2 - 3 } Age of sites(yr) & Organic C & Total N \\
\hline $1 \quad$ year & 1.7 & 1.8 \\
4 year & 2.2 & 2.3 \\
15 year & 2.6 & 2.5 \\
$40 \quad$ year & 2.8 & 2.6 \\
58 year & 2.6 & 2.4 \\
\hline Mature Sal forest & 2.5 & 2.2 \\
\hline
\end{tabular}


Percentage of microbial biomass carbon was minimum (1.7) in $1 \mathrm{yr}$ - old site and maximum (2.8) in $40 \mathrm{yr}$ - old site. Similarly, percentage of microbial biomass nitrogen was also minimum (1.8) in $1 \mathrm{yr}$ - old site and maximum (2.6) in $40 \mathrm{yr}$ - old site. ANOVA suggested that the variations in microbial biomass $\mathrm{C}$ and $\mathrm{N}$ were significantly different for sites $(\mathrm{P} \leq 0.001)$.

\section{Discussion}

Soil microbial biomass was lower in cropland system than the natural forest ecosystem. Soil microbial biomass is a potential source of plant nutrients, and a higher level of soil microbial biomass is an indicator of soil fertility (Garcia et al., 2002).In the cultivated land, the organic matter is not recycled as in the forest ecosystem. Within the cropping system, uncultivated paddy field for one year showed maximum MB-C and MB- $\mathrm{N}$ due to addition of organic matter in the soil as it happens in the grassland ecosystem. Soil with relatively higher organic matter input usually develops a larger microbial biomass. Soil microbial biomass is sensitive to changes through management practices, environmental fluctuation and cropping system (Shah et al., 2010).

Within the forest ecosystem, due to landslide disturbance, level of soil microbial biomass was reduced by $83 \%$ in 1-yr-old site in comparison to mature Sal forest. However, as the organic matter is added in soil during succession, the level of soil microbial biomass increased with passage of time and 58-yrs-old site showed $82 \%$ recovery in soil microbial biomass in relation to mature Sal forest. Recovery pattern was faster in the beginning (up to $15 \mathrm{yr}$ old) due to addition of soft and easily decomposable plant materials. Microbial biomass responds quickly to changes in soil management and is used as an indicator of soil quality (Chu \& Grogan, 2010).

MB-C: MB-N ratio was narrow (9.8) in tea cultivation and wide (11.3) in banana cultivation among the cropping systems while it was narrow (9.4) in $1 \mathrm{yr}$-old site and wide (11.6) in $58 \mathrm{yr}$ old site among the landslide sites. Similar range of MB-C: MB-N ratio (8.72 to 11.63) was reported by Kujur and Patel (2012) and (7.5 to 10.3) by Srivastava and Singh (1991) for certain Indian tropical soils and (8.7 to 13.2) by Dalal and Mayer (1987) for Australian arable soils. An increase in the size of microbial biomass is coupled with a widening of MB-C:MB-N ratio. Soil microflora is a composite of several group of organisms and each microbial group may have a different C:N ratio. C: $\mathrm{N}$ ratio of bacteria is often between 3-5, while in fungi it ranges from 7- 15 (Poul \& Clark, 1996). Lower MB-C:MB-N ratio represents bacterial dominance while higher MB-C:MB-N ratio represents fungal dominance in microbial biomass. Landslide disturbance altered both the size and composition of microbial biomass.

In the cropland system MB-C and MB-N as percentage of soil organic $\mathrm{C}$ and total $\mathrm{N}$ were relatively higher than forest ecosystem. The ratio of microbial biomass nutrient to soil nutrient present the quantum of soil nutrient reflected in microbial biomass, which provides an insight into the soil fertility status. Soil microbial biomass respond more rapidly to changes of soil environment than soil organic matter (Powlson et al., 1987).

Soil microbial biomass, represented a small fraction (2-3\%) of soil organic $\mathrm{C}$ and total N, which increased during the course of recovery of landslide sites. The values obtained for microbial biomass as percent of soil organic $\mathrm{C}$ and total $\mathrm{N}$ in the present study closely approximated with the values ( $2.8 \& 2.9 \%$, respectively) reported by Srivastava and Singh (1991) in dry tropical 
forest of India. Higher accumulation of soil microbial biomass at 58-yr - old site indicates the reestablishment of soil nutrients and restitution of nutrient cycling.

\section{Acknowledgements}

The author is grateful to Prof. Dr. K.P. Singh for guidance and to the Head, Department of Botany , Banaras Hindu University for providing the laboratory and library facilities. The author is also thankful to the Head, Department of Botany and the Campus Chief, Post Graduate Campus, Biratnagar for providing laboratory facilities.

\section{References}

Bonde, T.A., J. Schnurer \& T. Rosswall. 1988. Microbial biomass as fraction ass fraction of potentially mineralizable nitrogen in soils from long-term field experiments. Soil Biology \& Biochemistry 20: 447-452. http://dx.doi.org/10.1016/0038-0717(88)90056-9

Brookes, P.C., A. Landman, G. Pruden \& D.S. Jenkinson. 1985. Chloroform fumigation and the release of soil nitrogen: A rapid direct extraction method to measure microbial biomass nitrogen in soil. Soil Biology \& Biochemistry 17: 837-842. http://dx.doi.org/10.1016/00380717(85)90144-0

Chu, H. \& P. Grogan. 2010. Soil microbial biomass, nutrient availability and nitrogen mineralization potential among vegetation types in a low arctic tundra landscape. Plant Soil 329: 411-420. http://dx.doi.org/10.1007/s11104-009-0167-y

Dalal, R.C. \& R.J. Mayer. 1987. Long-term trends in fertility of soils under continuous cultivation and cereal cropping in Southern Queensland: VII. Dynamics of Nitrogen mineralization potentials and microbial biomass. Australia Journal of Soil Research 25: 461-472. http://dx.doi.org/10.1071/SR9870083

Fosu, M., R.F.Kunne \& P.L.G. Vlek. 2007. Mineralization and microbial biomass dynamics during decomposition of four leguminous residues. Journal of Biological Sciences 7: 632-637. http://dx.doi.org/10.3923/jbs.2007.632.637

Garcia, C., T. Hernandez, A. Roldan, \& A. Martin. 2002. Effect of plant cover decline on chemical and microbiological parameters under Mediterranean climate. Soil Biology \& Biochemistry 34: 632-635.

Kujur, M. \& A.K. Patel. 2012. Quantifying the contribution of different soil properties on microbial biomass carbon, nitrogen and phosphorus in dry tropical ecosystem. International Journal of Environmental Sciences 2( 3): 2272-2284.

Nsabimana, D., R.J. Haynes \& F.M. Wallis. 2004. Size, activity and catabolic diversity of the soil microbial biomass as affected by land use. Applied Soil Ecology 26: 81-92. http://dx.doi.org/ 10.1016/j.apsoil.2003.12.005

Parton, W.J., R.L.Sanford, P.A. Sanchez, \& J.W.B. Stewart. 1989. Modeling soil organic matter dynamics in tropical soils. Dynamics of Soil Organic Matter in Tropical Ecosystems (Coleman, D.C., J.M. Oades \& G. Uehara. Eds.), pp. 153-171. University of Hawaii Press, Honolulu.

Paul, E.A. \& F.E. Clark. 1996. Soil Microbiology \& Biochemistry. Academic Press, San Diego. 340p.

Powlson, D.S., P.C. Brookes, \& B.T. Chreistensen. 1987. Measurement of soil microbial biomass provides an early indication of changes in total soil matter due to straw incorporation. Soil Biology \& Biochemistry 19: 159-164. http://dx.doi.org/10.1016/0038-0717 (87)90076-9 
Schnürer, J., M. Clarholm \& T. Rosswall. 1985. Microbial biomass and activity in an agricultural soil with different organic matter contents. Soil Biology \& Biochemistry 17: 611-618. http://dx.doi.org/10.1016/0038-0717 (85)90036-7

Shah, Z., S.R. Ahmad \& H.U. Rahman. 2010. Soil microbial biomass and activities as influenced by green manure legumes and $\mathrm{N}$-fertilizer in rice wheat system. Pakistan Journal of Botany 42(4): 2589-2598.

Smith, L.J. \& R.I. Papendick. 1993. Soil organic matter dynamics and crop residue management. In: Soil Microbial Ecology (Meeting, B. \& Marcel Dekker. Eds.), New York.

Srivastava, S.C. \& J.S. Singh. 1991. Microbial C, N and P in dry tropical forest soils : Effects of alternate land-uses and nutrient flux. Soil Biology \& Biochemistry 23: 117-124. http://dx.doi. org/10.1016/0038-0717(91)90122-Z

Vance, E.D., P.C. Brookes \& D.S. Jenkinson. 1987. An extraction method for measuring soil microbial biomass C. Soil Biology \& Biochemistry 19: 703-707. http://dx.doi.org/10.1016/ 0038-0717 (87)90052-6 